\title{
Peran Massive Open Online Courses dalam Pendidikan Agama Islam di era digital
}

\author{
Sumarsono \\ UIN Sunan Kalijaga Yogyakarta \\ sumarsono@uin-suka.ac.id
}

\begin{abstract}
This article discusses the learning of Islamic Religious Education (PAI) in the digital era, the opportunities and challenges of MOOC through the Massive Open Online Course (MOOC) media associated with the concept of independent learning. The research method used a qualitative descriptive approach. Through the independent learning approach, learners explore knowledge and information independently and gain knowledge from learning experiences. The availability of course themes (course designs) that suit learners in the MOOC program greatly determines the success of increasing the quality of learning, especially regarding Islamic Religious Education (PAI) learning. Until now there has been no Islamic Religious College that has developed the MOOC on PAI which can be used collectively. The final result of this article is a research on the opportunities for developing adaptive MOOCs in Islamic higher education institutions, especially the PAI study program which is harmonized with the application of learning. Through the adaptive MOOC, it is hoped that the strengthening of PAI learning outcomes from the start in the form of materials can become characters and values through monitoring and assessment props using MOOC technology.
\end{abstract}

Keywords: MOOC's, islamic religious education; digital age; independent learning

\begin{abstract}
Abstrak
Artikel ini membahas pembelajaran Pendidikan Agama Islam (PAI) di era digital, peluang dan tantangan memanfaatkan media Massive Open Online Course (MOOC) adaptif diselaraskan dengan kurikulum merdeka belajar. Metode penelitian menggunakan pendekatan deskriptif kualitatif. Melalui pendekatan merdeka belajar, pembelajar mengeksplorasi pengetahuan dan informasi secara mandiri dan memperoleh pengetahuan dari pengalaman belajar. Ketersediaan tema kursus (course design) yang sesuai dengan pembelajar dalam MOOC sangat menentukan keberhasilan peningkatan kualitas pembelajaran khususnya tentang Pendidikan Agama Islam (PAI). Penggunaan media pembelajaran MOOC tentang PAI yang digunakan secara bersama kolaboratif antar perguruan tinggi akan memberikan dampak signifikan dalam memajukan pendidikan Islam di Indonesia. Hasil akhir dari artikel ini adalah sebuah pemikiran memanfaatkan peluang media pembelajaran MOOC yang disusun adaptif di Perguruan Tinggi Agama Islam diselaraskan dengan kurikulum merdeka belajar. Melalui konstruksi MOOC adaptif sesuai karakteristik Perguruan Tinggi Agama Islam mampu memberikan solusi dalam penguatan capaian pembelajaran khususnya ranah sikap dan tata nilai.
\end{abstract}

Kata kunci: MOOC, Pendidikan Agama Islam, merdeka belajar

Diserahkan: 21-09-2021 Disetujui: 01-03-2021. Dipublikasikan: 04-03-2021

Kutipan: Sumarsono, S. (2021). Peran Massive Open Online Courses dalam Pendidikan Agama Islam di era digital. Ta'dibuna: Jurnal Pendidikan Islam, 10(1). doi:http://dx.doi.org/10.32832/tadibuna.v10i1.3451 


\section{Pendahuluan}

Penggunaan Teknologi Informasi dan Komunikasi menjadi sebuah keniscayaan di era digital mempengaruhi hampir seluruh aspek kehidupan manusia dengan alam sekitar termasuk dalam dunia pendidikan baik dasar, menengah hingga Pendidikan tinggi, bahkan Pendidikan luar sekolah. Pengaruh digitalisasi ini tentu mempengaruhi perubahan budaya di masyarakat (Rahmawati, 2018). Perkembangan teknologi di era Revolusi Industri 4.0 banyak disebut pakar pendidikan sebagai sebuah momentum perubahan pendidikan di Indonesia seiring dengan semakin meluasnya penggunaan mesin cerdas, menghubungkan komunikasi antar manusia melalui mesin internet termasuk hubungan dalam pembelajaran antara dosen dengan mahasiswa. Suatu era di mana hubungan dosen dengan mahasiswa telah bergeser dari konvensional menjadi modern melalui pembelajaran online (daring), bersifat terbuka dan fleksibel (Bilfaqih \& Qomarudin, 2015). Saat ini komunikasi dosen dengan mahasiswa telah mengalami perubahan paradigma baru yang membutuhkan kesiapan teknik dan non teknis. Dalam pola lama konteks pembelajaran tradisional dilaksanakan dengan pendekatan pedagogi di dalam kelas, fungsi dosen sebagai sentral dalam kegiatan pembelajaran, dosen sebagai sumber utama pengetahuan dan pengalaman belajar (Oey-Gardiner dkk., 2007).

Dalam pembelajaran modern saat ini semakin memantapkan langkah bahwa konsep pembelajaran yang berpusat pada dosen beralih pada berpusat pada peserta didik (student centered) (Løkse dkk., 2017). Dalam konteks pendidikan Islam modern, pergeseran dan perubahan tersebut bukan lagi sebuah wacana yang diperdebatkan namun sudah saatnya untuk dilaksanakan, mengingat laju perkembangan ilmu pengetahuan dan teknologi begitu cepat dan kebutuhan manusia mengalami perubahan dan tantangan untuk terus berubah menuju perbaikan dan peningkatan kualitas pembelajaran dan kualitas hasil pembelajaran (Irmayani dkk., 2018). Sebuah era baru dapat dianggap sebagai sebuah peluang bagi peningkatan kualitas pembelajaran, menciptakan inovasi strategi pembelajaran (Nana \& Surahman, 2019), menggunakan teknologi yang mendukung sistem pembelajaran modern (Mustaghfiroh, 2020), perbaikan tata kelola, perubahan kurikulum berbasis luaran (Amirudin, 2019), peningkatan kompetensi sumber daya manusia, peningkatan sarana dan prasarana, menumbuhkan karakter (Reflianto \& Syamsuar, 2019), sikap dan tata nilai yang lebih baik (Hase, 2009).

Pembelajaran era baru memberikan peluang lebih besar kepada pembelajar dalam mengeksplorasi dan mengembangkan pengetahuan dan ketrampilan menggunakan teknologi. Mahasiswa dapat belajar secara mandiri, mengikuti kursus tentang tema dan topik yang diinginkan sesuai dengan capaian pembelajaran yang diinginkan. Saat ini terdapat media pembelajaran yang mewadahi peluang tersebut yaitu Massive Open Online Courses (MOOC), sebuah kursus online yang ditawarkan secara terbuka oleh banyak penyelenggara baik dilakukan oleh perusahaan maupun Lembaga Pendidikan. 
Teknis penyajian materi disampaikan secara terbuka kepada masyarakat yang ingin mengikutinya, materi disajikan dalam suatu kelas online sebagai inovasi pembelajaran yang menghubungkan komunikasi antara pengajar dan pembelajar melalui media pembelajaran yang secara komprehensif saling melengkapi seperti gambar, teks, audio dan video (Abbakumov dkk., 2018). Dalam model pembelajaran MOOC ini, pembelajar dapat menerima pengetahuan dan informasi, mengeksplorasi pengetahuan dan memperoleh pengalaman dari pembelajar yang lain, mengikuti ujian dan mendapatkan sertifikat atas hasil ujian. Namun demikian, hingga saat ini pembelajaran melalui MOOC masih memiliki kendala dalam memaksimalkan partisipasi aktif pembelajar mengikuti pembelajaran dari awal sampai akhir (Borrás-Gené, 2019; Zhu \& Bonk, t.t.), menentukan waktu pembelajaran sesuai dengan kebiasaan pembelajar, memaksimalkan keterlibatan dalam pembelajaran online (Malek, 2017), memilih konten yang sesuai dengan capaian pembelajaran. Banyak lembaga yang menyediakan fasilitas pembelajaran melalui MOOC dengan berbagai variasi layanannya yang beragam di antaranya adalah open content (Brahimi \& Sarirete, 2015), open courseware (Allison dkk., 2012), open education (Bertrand dkk., 2019) dan open certified (Gardair dkk., 2017).

Open content berisi materi ilmu pengetahuan, open courseware berisi tentang materi perkuliahan, open education berisi tentang materi pembelajaran yang disajikan secara lengkap sesuai Standard Nasional Pendidikan Tinggi yaitu proses pembelajaran hingga evaluasi pembelajarannya. Open Education ini memberikan peluang besar dalam penyelenggaraan media MOOC bersama antar perguruan tinggi, penyelenggaraannya dilakukan secara kolaborasi antar dosen, antar mahasiswa dan antar perguruan tinggi. Dari proses pembelajaran yang melibatkan banyak dosen dari multidisiplin keilmuan yang tersebar di perguruan tinggi akan memberikan dampak sangat besar dalam penguatan kajian wawasan keilmuan dan pengalaman bagi peserta. Diskusi dalam pembelajaran kolaborasi ini menjadi lebih hidup, mahasiswa mendapatkan pengalaman dari pembelajar lain, bahkan dosen pun akan banyak belajar dari mahasiswa. Open certified memberikan akses program sertifikasi profesi bagi mahasiswa melalui lembaga sertifikasi profesi.

Pendidikan Agama Islam dengan berbagai tingkatannya mulai dari pendidikan dasar, menengah dan tinggi harus mampu menjawab masalah tantangan sekaligus peluang yang dihadapi di era globalisasi dan digitalisasi. Saat ini dunia pendidikan telah memasuki persaingan yang semakin ketat seiring dengan penggunaan layanan pendidikan berbasis teknologi modern, pelayanan menjadi lebih cepat dan akurat, perkembangan big data melalui interkoneksi data dan informasi antar satu cabang ilmu dengan ilmu lain, berubahnya mindset dari idealis menjadi pragmatis pendidikan (Rosidin, 2016). Hal ini perlu disikapi oleh pelaku Pendidikan Agama Islam dengan arif dan bijaksana menyesuaikan perkembangan teknologi informasi, tidak menghindari kenyataan atau 
bahkan menolaknya, namun justru harus mampu mengambil manfaat sebesar besarnya untuk perbaikan Pendidikan Agama Islam ke depan.

Berikutnya adalah bagaimana mengambil manfaat keberadaan MOOC bagi kemaslahatan umat manusia khususnya Pendidikan Agama Islam agar mampu bersaing dalam dunia global dengan tetap berpegang teguh pada Qur'an dan Sunnah, menjaga kualitas pembelajaran PAI sesuai dengan kaidah dan aspek ranah KKNI yaitu sikap dan tata nilai, pengetahuan dan ketrampilan. Media MOOC perlu dimaksimalkan fungsi dan fasilitasnya untuk mendukung pencapaian pembelajaran sesuai dengan standar yang berlaku. Mahasiswa memiliki hak dan kesempatan meningkatkan kompetensinya melalui program merdeka belajar selama 3 semester di luar program studi sesuai dengan capaian pembelajaran lulusan yang telah ditetapkan oleh program studinya. Namun mengingat ketersediaan sarana prasarana yang terbatas, baik dari sisi gedung kuliah, anggaran pendidikan, standar kurikulum, dosen pengajar, bahan materi ajar, strategi pembelajaran berbasis teknologi, sistem e-learning maka dibutuhkan suatu solusi untuk diselesaikan bersama antar Perguruan Tinggi Agama Islam secara terpadu dan komprehensif.

Melalui pemikiran adanya program open education dari MOOC dan sekaligus menyambut program merdeka belajar, maka kedua hal tersebut dapat diselaraskan melalui suatu kerja sama penyelenggaraan layanan pendidikan bersama antar Perguruan Tinggi Agama Islam. Bentuk layanan pendidikan merdeka belajar yang diselenggarakan secara kolaboratif antar perguruan tinggi berbasis teknologi MOOC ini melibatkan unsur pokok yaitu dosen pengajar berikut dengan capaian pembelajaran mata kuliah, materi ajar, dan strategi pembelajaran dan sistem penilaian. Untuk melaksanakan program ini tidaklah mudah, membutuhkan banyak persiapan khususnya mindset sumber daya manusia baik dosen dan mahasiswa bahwa zaman telah berubah, penggunaan teknologi menjadi kebutuhan pokok dalam pembelajaran untuk meningkatkan kompetensi dan pengalaman mahasiswa sebagai pembelajar masa depan.

\section{Metode Penelitian}

Metode kajian penelitian ini adalah deskriptif kualitatif. Metode ini digunakan untuk mengkaji fenomena dan kondisi pendidikan di Indonesia khususnya di Perguruan Tinggi Agama Islam di tengah percaturan global terkait penggunaan teknologi media pembelajaran berbasis internet MOOC. Melalui metode ini, peneliti melakukan kolaborasi kajian literatur tentang penggunaan media pembelajaran MOOC yang diselaraskan dengan keinginan meningkatkan kualitas pendidikan Agama Islam khususnya ranah sikap dan tata nilai yang selama ini masih menjadi masalah dalam media pembelajaran MO0C. Penelitian deskriptif ini untuk membuat deskripsi dan gambaran secara sistematis tentang desain pembelajaran yang adaptif dengan mengkorelasikan antar unsur-unsur yang berperan dalam kurikulum merdeka belajar. 


\section{Hasil dan Pembahasan}

\section{A. Pengembangan Pembelajaran PAI di era Digital}

Pada dasarnya pendidikan itu mempersiapkan manusia untuk menjalankan perannya dalam kehidupan, peran manusia dengan Tuhannya, sesama manusia dan manusia dengan alam semesta. Pendidikan tidak boleh lepas dari nilai (Mukti, 2018), akidah keyakinan, ketrampilan teknis hingga kesalehan (Suwandaru dkk., 2018). Shaleh yang proporsional mengandung nilai-nilai kebenaran logika, nilai kebaikan etika dan memberikan kemanfaatan pragmatisme yang terintegrasi dari 3 hal tersebut.

Science menekankan pada kebendaan, humaniora menekankan pada kebaikan dan teknologi menekankan pragmatisme, ketiganya menjadi satu kesatuan yang tidak bisa dilepaskan. Saat ini permasalahan pembelajaran PAI tidak sekedar masalah kurikulum pendidikan, namun juga masalah teknis. Minimnya Informasi pembelajaran keagamaan melalui internet menjadi salah satu faktor yang mempengaruhinya. Minimnya ketersediaan materi pembelajaran keagamaan yang menarik, faktor sumber daya manusia kurang memiliki kemampuan teknis menuangkan materi pembelajaran dalam bentuk digital.

Perumusan konsep pendidikan mengacu pada tujuan Pendidikan di Indonesia menurut UU No. 20 tahun 2003 pasal 3 yaitu mengembangkan potensi peserta didik memiliki keimanan, ketakwaan, cerdas, kreatif, sehat dan bertanggungjawab. Membentuk peserta didik menjadi makhluk Tuhan yang beriman dan beragama, berkembang akal, otak, kecerdasan sehingga berkembang menjadi pribadi yang cerdas, kreatif, dan cakap, demokratis dan bertanggungjawab. Untuk mewujudkan hal tersebut, diperlukan kurikulum yang mencantumkan Agama, Kewarganegaraan dan Bahasa. Ketika bicara karakter dan budi pekerti sesungguhnya itu sudah sebagai bagian dari nilainilai Agama.

Adanya masalah karakter peserta didik yang kurang baik disebabkan oleh adanya inkonsistensi antara rumusan kurikulum dengan pelaksanaan di lapangan. Dibutuhkan konsistensi implementasi karakter dan nilai dalam pembelajaran di sekolah tidak hanya masalah material. Perlu ada perubahan mindset di masyarakat terkait capaian pembelajaran dari material kepada karakter dan nilai. Tidak cukup mudah untuk melakukan dan mengimplementasikan nilai-nilai karakter di sekolah, dibutuhkan suatu alat penilaian berupa variabel atau parameter untuk melakukan pemantauan menggunakan media teknologi.

Dalam era digital saat ini sangat memungkinkan melakukan pemantauan perkembangan nilai dan karakter siswa. Permasalahan lainnya adalah model pembelajaran Pendidikan Agama Islam membutuhkan inovasi pembelajaran interaktif yang membangun komunikasi intensif humanistis, membangkitkan daya nalar dan kritis pelajar. 


\section{B. Kontribusi MO0C untuk Pendidikan}

MOOC sebagai suatu media pembelajaran terbuka yang dilakukan secara online untuk menjangkau audience dari jarak jauh yang dilakukan secara synchronous dan asynchronous dengan cakupan peserta yang banyak tanpa dibatasi jarak dan waktu. Membangun komunikasi dan berbagi pengalaman belajar untuk meningkatkan kompetensi pembelajaran mandiri melalui metode kursus online (Baturay, 2015). Metode pengajaran dalam MOOC adalah komunikasi antara instruktur dengan siswa dibangun melalui sistem manajemen online baik berbasis kelas maupun non kelas (Cohen \& Soffer, 2015). Ada 2 dimensi pendekatan komunikasi dalam MOOC yaitu cMOOC dan xMOOC, di mana yang pertama (cMOOC) menggunakan pendekatan connectivisme untuk menghubungkan komunikasi dengan pembelajar dan yang kedua 2 (xMOOC) menggunakan pendekatan behaviorism secara lebih terstruktur (Kaplan \& Haenlein, 2016). Elemen dari MOOC (Watted \& Barak, 2018) disajikan dalam gambar 1 berikut.

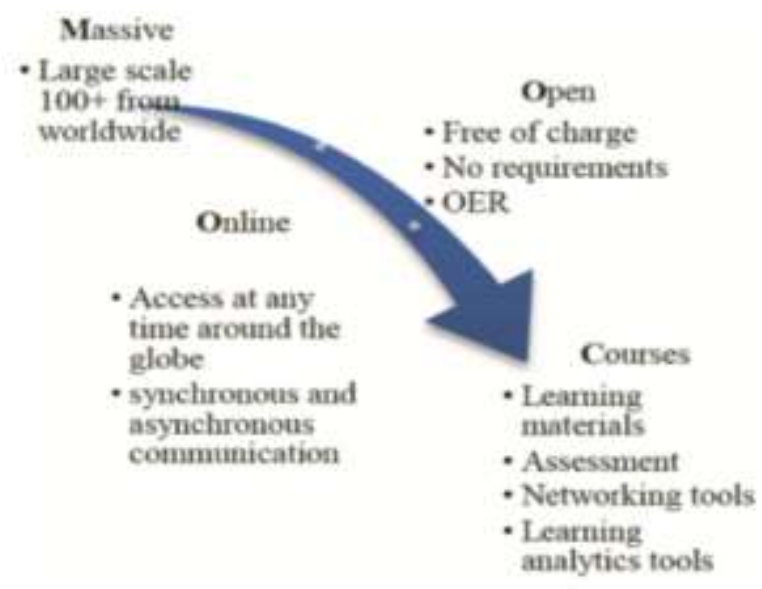

Gambar 1. Elemen MOOC

Terdapat empat huruf dalam MOOC yang memiliki makna tersendiri yakni: pertama Massive, MOOC memiliki prinsip infinite scalability yaitu tidak membatasi jumlah peserta MOOC selama kapasitas perangkat server mampu menampung semua data informasinya dan memiliki algoritma yang baik dalam mengatasi kompleksitas sistem. kedua Open, keanggotaannya bersifat terbuka tetapi memegang teguh kode etik dan norma. Sifat keanggotaan bisa gratis atau berbayar tergantung pada program fasilitas yang diikuti. Beberapa institusi pendidikan maupun non pendidikan telah mengembangkan platform MOOC dengan mengajak peserta sebanyak banyaknya dalam rangka menyebarkan ilmu pengetahuan dan pengalaman baru bagi masyarakat luas. ketiga Online, MOOC menyediakan fasilitas untuk mendukung pembelajaran tatap muka, semua materi perkuliahan, bahan bacaan, penugasan, praktikum, soal ujian dan lain-lain di-upload ke sistem MOOC. Penyajian materi disampaikan secara synchronous dan asynchronous sehingga memberi kesempatan bagi yang menginginkan tatap muka langsung dengan 
pengajar melakukan pertanyaan secara langsung maupun belajar tidak secara langsung bertemu pada satu saat dengan pengajarnya. Keempat Courses, MOOC merupakan suatu bentuk kursus yang dikemas secara utuh mulai dari pengaturan kelas, materi yang disajikan, bahan bacaan, aturan perkuliahan, praktikum, penugasan, pelaksanaan ujian dan penilaian. target utama dari kursus ini adalah bagaimana meningkatkan engagement peserta kursus sehingga memudahkan pengajar melalukan pemantauan perkembangan proses pembelajaran peserta didik selama mengikuti pembelajaran online.

Pembelajaran cMOOC didasarkan pada interaktivitas dengan teman sebaya. Pembelajar didorong untuk menggunakan kelas online guna mengejar tujuan pembelajaran masing-masing individu dan mengatur sendiri partisipasi mereka (Amamou \& Cheniti-Belcadhi, 2018). Sementara xMOOC lebih terstruktur dengan menekankan pembelajaran individu melalui ceramah video, penilaian reguler, kuis dinilai otomatis, penilaian sejawat atau mandiri, dan online (Kaplan \& Haenlein, 2016). xMOOC biasanya ditawarkan oleh universitas karena xMOOC lebih tersentralisasi. Adapun karakteristik dari cMOOC disajikan dalam gambar 2 berikut

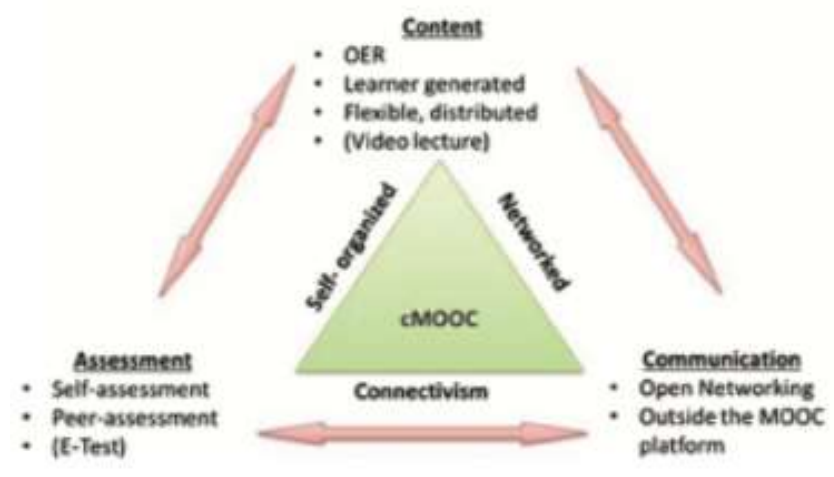

Gambar 2. Karakteristik cMOOC

Pembelajaran cMOOC merupakan belajar kelompok dengan mengumpulkan penggunanya berdiskusi bersama membahas suatu topik tertentu, setiap pengguna memberikan tanggapan dan solusinya melalui media yang disepakati bersama seperti weblog (Joksimović dkk., 2018). Dalam lingkungan cM00C, semua peserta dianggap sebagai pembelajar dengan prinsip pedagogi connectivist. Bahan diskusi disampaikan terlebih dahulu kemudian pengguna yang lain menyimak, mempelajari melakukan koreksi. Pendekatan desain instruksional cMOOC berusaha untuk menghubungkan antar pengguna untuk menjawab pertanyaan atau berkolaborasi pada proyek bersama secara kolaboratif dalam rangka membangun pengetahuan bersama antar pembelajar (Lambert, 2020).

xMOOC kepanjangan dari eXtended Massive Open Online Course yaitu kursus online yang didasarkan pada program universitas tradisional yang secara signifikan memperluas jumlah siswa yang dapat terkena kursus tingkat universitas (García-Peñalvo 
dkk., 2018). Konsep xMOOC adalah menempatkan sisi guru dan siswa pada sisi yang berbeda, di mana setiap individu adalah pelajar atau pengajar. Beberapa praktisi berpendapat bahwa xMOOC lebih rendah kualitasnya karena menghilangkan interaksi pengajar-pelajar secara langsung dan melibatkan interaksi siswa-siswa yang terbatas. Beberapa platform xMOOC yang ada di internet adalah edX, Coursera, dan Udacity (Kesim \& Altınpulluk, 2015). Karakteristik xMOOC disajikan dalam gambar 3 berikut

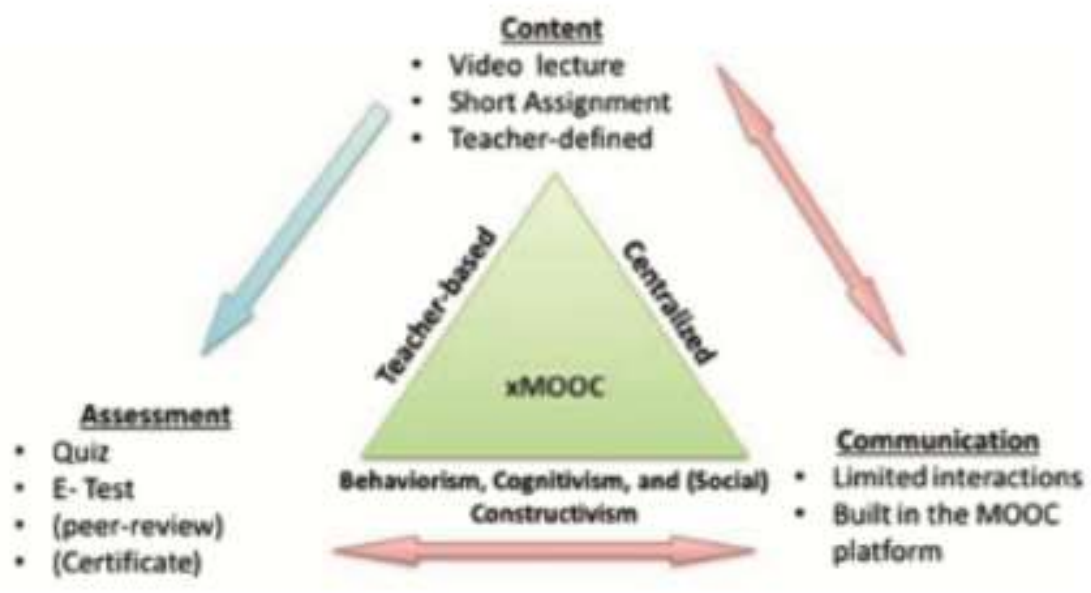

Gambar 3. Karakteristik xMOOC

Berdasarkan karakteristik dari CMOOC dan XMOOC tersebut, peluang pembelajaran menggunakan MOOC sangat terbuka lebar dalam upaya meningkatkan kualitas pembelajaran dengan memberikan akses pengetahuan dan pengalaman kepada pembelajar yang dengan mudah mengakses sumber belajar dengan didukung oleh fitur teknologi seperti interaksi, kolaborasi, refleksi diri dan sistem evaluasi (Weinhardt \& Sitzmann, 2019). Alat-alat yang digunakan dalam literatur MOOC diklasifikasikan dalam tiga kategori yaitu alat kolaborasi, penilaian, dan analitik. Alat untuk mendukung peserta didik dalam berkomunikasi satu sama lain seperti forum, blog, siaran video, jejaring sosial, dan dasbor (Torres-Coronas \& Vidal-Blasco, t.t.). dari dua jenis MOOCs tersebut dalam melalukan penilaian terhadap peserta menggunakan metode elektronik berbeda beda (Wrigley dkk., 2018). Dalam cMOOC lebih fokus pada penilaian diri dan penilaian sejawat (Otto dkk., 2019). Sementara xMOOC lebih fokus pada penggunaan tes tradisional sedangkan penilaian pada kuis menggunakan e-assessment (Ramírez-Montoya dkk., 2017).

Beberapa studi terkait alat analisis MOOC yaitu mencoba menerapkan alat analisis pembelajaran untuk memantau proses pembelajaran, mengidentifikasi kesulitan, menemukan pola belajar, memberikan umpan balik, dan mendukung peserta didik dalam merefleksikan pengalaman belajar mereka sendiri (Hew \& Cheung, 2014). Namun demikian dalam MOOC masih ada beberapa hal yang membutuhkan pemikiran dan solusi 
ke-depan yaitu bagaimana memberikan umpan balik pribadi kepada sejumlah besar siswa yang mengikuti kursus online. (Aidemark \& Askenäs, 2019)

Berdasarkan sumber referensi dari MOOC-list.com, diperoleh beberapa kategori kursus yang disediakan oleh provider Internasional disajikan dalam tabel 1.

Tabel 1. Kategori Kursus MOOC Internasional hingga tahun 2019

\begin{tabular}{|c|c|c|}
\hline No. & Nama Kategori & Sub Kategori \\
\hline 1 & Seni dan Budaya & $\begin{array}{l}\text { Arsitektur \& Desain } \\
\text { Musik, Film \& Audio }\end{array}$ \\
\hline 2 & Bisnis & $\begin{array}{c}\text { Manajemen dan kepemimpinan } \\
\text { Keuangan dan ekonomi } \\
\text { Pemasaran dan komunikasi }\end{array}$ \\
\hline 3 & Ilmu Komputer & $\begin{array}{l}\text { Kecerdasan buatan, robotika } \\
\text { Teknik informasi } \\
\text { Pemrograman } \\
\text { Perancangan Perangkat lunak } \\
\text { Keamanan jaringan } \\
\end{array}$ \\
\hline 4 & Data Science & Statistik dan data analisis \\
\hline 5 & Pendidikan & $\begin{array}{c}\text { Pendidikan sains } \\
\text { Pendidikan agama } \\
\text { Pendidikan teknik }\end{array}$ \\
\hline 6 & Teknik & $\begin{array}{c}\text { Elektronika } \\
\text { Arsitektur } \\
\text { Lingkungan }\end{array}$ \\
\hline 7 & Kesehatan Masyarakat & $\begin{array}{c}\text { Makanan dan nutrisi } \\
\text { Kedokteran dan farmakologi }\end{array}$ \\
\hline 8 & Humaniora & $\begin{array}{c}\text { Sejarah } \\
\text { Bahasa dan perpustakaan } \\
\text { Hukum } \\
\text { Olahraga }\end{array}$ \\
\hline 9 & Pengembangan Pribadi dan Profesional & Bimbingan Konseling \\
\hline 10 & Sains & $\begin{array}{c}\text { Biologi dan ilmu kehidupan } \\
\text { Kimia } \\
\text { SciEnergi dan ilmu bumi } \\
\text { Lingkungan } \\
\text { Matematika } \\
\text { Ilmu Fisika dan bumi } \\
\end{array}$ \\
\hline 11 & Ilmu Sosial & $\begin{array}{c}\text { Geografi } \\
\text { Sosiologi } \\
\text { Antropologi } \\
\text { Psikologi } \\
\text { Ilmu komunikasi } \\
\end{array}$ \\
\hline
\end{tabular}

\section{MO0C di Era Keterbukaan Merdeka Belajar}

Pendidikan terbuka identik dengan pola keterbukaan akses sumber belajar, sikap terbuka praktik belajar mengajar, penyediaan akses terbuka dan kemudahan diakses (Prawitasari \& Suharto, 2020). Pendidikan terbuka ini selaras dengan paradigma merdeka belajar yang mengedepankan kemerdekaan berpikir bagi semua sumber daya 
manusia yang ada disekolah baik pengajar maupun pembelajar. Merdeka belajar merupakan suatu usaha untuk menghormati perubahan secara masif dan dinamis agar pembelajaran itu dapat terjadi di berbagai macam institusi Pendidikan. Dalam merdeka belajar, siswa dapat menentukan sendiri strategi belajarnya, mencari sumber belajarnya namun harus tetap mengacu pada capaian pembelajaran yang telah ditetapkan dalam kurikulum (Sumarsono, 2020).

Terkait konsep kampus merdeka dan merdeka belajar seperti tertuang dalam Permendikbud No. 3 tahun 2020, bahwa mahasiswa mendapatkan hak belajar di luar di luar program studi selama 3 semester melalui 8 (delapan) bentuk kegiatan yaitu pertukaran pelajar, magang/praktik kerja, asisten mengajar di satuan pendidikan, penelitian/ riset, proyek kemanusian, kegiatan wirausaha, studi / proyek independen, membangun desa/tematik. Hak belajar di luar kampus dapat dimaknai dan diselaraskan dengan program pengembangan pengetahuan dan ketrampilan melalui pengalaman di tempat lain agar mendapatkan wacana baru yang saling melengkapi. Selama mengikuti program merdeka belajar, mahasiswa tidak sepenuhnya terbebas dari pantauan dosen pendamping selama mengikuti merdeka belajar. Mahasiswa harus tetap berada dalam bimbingan dosen pendamping yang ditunjuk oleh ketua program studi sebagai sarana diskusi dan membantu memberikan solusi sekaligus melakukan penilaian. Selama pelaksanaan merdeka belajar akan terjadi potensi kesenjangan pengetahuan antara di dalam kampus maupun di luar kampus, adanya perbedaan implementasi antara teori dan praktik akibat tidak meratanya tingkat pendidikan dan kemampuan akademik masyarakat. Untuk mewujudkan tersebut diperlukan suatu media penghubung antara dosen dan mahasiswa, mahasiswa dengan tempat belajar di luar melalui media Massive Open Online Cources (MOOC).

MOOC sebagai sebuah sistem hadir untuk mengurangi kesenjangan pengetahuan yang kurang merata (Løkse dkk., 2017). Hadir untuk memberikan solusi yang dapat mengatasi masalah kesenjangan tersebut, kehadiran kursus model ini merupakan reaksi positif terhadap kebutuhan dan permasalahan pembelajaran di era digital sehingga memudahkan bagi pembelajar memaksimalkan pengetahuan dan pengalaman belajarnya (Topîrceanu, 2017). Hal ini juga sejalan dengan program kampus merdeka dan merdeka belajar dari Menteri Pendidikan dan Kebudayaan dalam memberikan layanan pembelajaran yang tidak hanya terbatas pada lingkungan belajarnya, namun memiliki kesempatan waktu dan ruang yang lain untuk menambah kompetensi, kemampuan yang lebih baik dari sisi akademik maupun pengembangan profesi. Tantangan utama dari MOOC adalah masalah skalabilitas umpan balik dan dukungan dari pengguna MOOC yang dengan mudah memutuskan keluar dari keanggotaan MOOC setiap saat (Douglas dkk., 2020). Hal ini dipengaruhi oleh karakter non-formal MOOC dan hasil yang tidak jelas dapat dengan mudah menyebabkan perilaku tidak komitmen dari pembelajar. 
Namun demikian untuk penyempurnaan MOOC ke depannya perlu mempertimbangkan faktor sosial masyarakat penggunanya (Cai dkk., 2020), karakteristik budaya (Karnouskos, 2017) dan kebiasaan pembelajar (Zhang, 2019) yang mempengaruhi sikap dan perilaku pembelajar dalam menggunakan desain pembelajaran. Kesuksesan program belajar sangat didukung oleh ketersediaan fasilitas yang terjangkau masyarakat umum khususnya bagi masyarakat miskin. Faktor keberpihakan institusi atau pemerintah dalam menyediakan fasilitas MOOC sangat penting dan sangat mempengaruhi kesuksesan program MOOC di Indonesia (Chrysantina dkk., 2019). Penyediaan MOOC secara gratis bagi masyarakat sangat penting artinya bagi kesuksesan program merdeka belajar yang dapat diakses seluruh anak bangsa dengan melengkapi harapan masyarakat yaitu:

Setiap pengguna adalah pembelajar, di suatu saat menjadi pelajar dan di saat yang lain menjadi pengajar sehingga dimungkinkan memiliki akses untuk membuat kelas dan mengikuti kelas. Ketika membuat kelas akan berfungsi sebagai pengajar, sedangkan mengikuti kelas berfungsi sebagai pelajar.

Menggerakkan berbagai yayasan pendidikan Islam membentuk MOOC terpadu secara terintegrasi antar sekolah. MOOC terpadu ini akan mempercepat proses penyebaran materi dan inovasi pembelajaran dari satu pengajar ke pengajar yang lain, dari satu sekolah ke sekolah yang lain, dari satu murid ke murid yang lain. MOOC memberikan kesempatan bagi masyarakat untuk memiliki keahlian berstandar internasional melalui program MOOC Certified.

\section{Potensi MO0C dalam Pendidikan Agama Islam}

Perubahan jaman yang ditandai dengan perkembangan revolusi Industri mulai dari ke 1 hingga saat ini yang ke 4 telah menjadikan manusia sebagai makhluk yang sangat diuntungkan dan dimudahkan dalam berhubungan dan silaturahmi dengan orang lain melalui media internet (Stokols, 2018), dapat mengakses semua informasi yang diinginkan secara mandiri dengan tetap berpegang teguh pada asas tata krama, tata susila, kode etik (Gregory dkk., 2018). Revolusi ini secara otomatis akan mengubah tatanan kehidupan khususnya didunia pendidikan Islam (Mawardi, 2013). Perubahan dari pembelajaran tradisional menuju kepada pembelajaran online yang tersambung dengan layanan internet. Pergeseran paradigma belajar dengan dari tradisional menjadi online learning juga berimbas pada pendidikan Agama Islam (Rahmawati, 2018).

Pembelajaran PAI dapat memanfaatkan teknologi informasi untuk meningkatkan kualitas mutu Pendidikan Agama Islam melalui proses belajar mengajar dikelas maupun di luar kelas menggunakan berbagai macam media sosial dengan segala konsekuensinya termasuk perubahan perilaku penggunanya baik pengajar maupun peserta didik (Abidin \& Fahmi, 2019). Aksesibilitas pembelajar terhadap ketersediaan sumber belajar yang sangat terbuka, beragam dan tidak terbatas melalui MOOC mampu meningkatkan 
kompetensi pembelajar. Munculnya pembelajaran kelas virtual (Lei dkk., 2019), pembelajaran online daring (khususnya dimasa pandemik COVID-19) yang mengharuskan menjaga protokol kesehatan jaga jarak dan tidak bertemu secara tatap muka (Pangeni, 2017) tentu akan menjadi permasalahan tersendiri yaitu terdegradasinya faktor keteladanan pengajar. Pengajar memiliki tugas utama mendidik dan mengarahkan siswa untuk membentuk insan kamil yang bertakwa pada Allah (Prasetyo dkk., 2019). Munculnya layanan aplikasi pendidikan (Praherdhiono dkk., 2019) dan ketrampilan mobile dan responsif, kurikulum yang mengedepankan kebutuhan personal, pembelajaran mandiri, layanan konten tanpa batas secara online dan gratis, platform pendidikan kolaboratif akan menjadi suatu gelombang disrupsi dalam dunia Pendidikan. MOOC sebagai bagian dari e-learning bertujuan untuk menebar manfaat bagi masyarakat luas baik tersebar di seluruh antero dunia di desa maupun di kota dalam mendapatkan hak yang sama memperoleh kesempatan belajar, terlepas dari kelemahan MOOC dalam hal infiltrasi yang mempengaruhi nilai-nilai keislaman (Fikri, 2019).

Dalam pembelajaran MOOC, antar pembelajar tidak melakukan tatap muka langsung, namun pertemuan dilakukan secara online jarak jauh. Pengajaran dilakukan kapan saja dan di mana saja. Permasalahan yang muncul kemudian adalah masalah fokus, pengajar menjadi tidak fokus ketika melakukan pengajaran secara online. Namun demikian hal ini dapat diselesaikan dengan menyiapkan perangkat pembelajaran lebih dini sebelum pelaksanaan pembelajaran online. Pengajar harus menyiapkan course design (Islam dkk., 2015) yang mencakup semua kegiatan pembelajaran yang sesuai dengan kaidah ilmu Pendidikan sehingga tujuan pembelajaran yang dicita-citakan dapat tercapai dengan efektif dan efisien menghasilkan output yang memiliki kualitas baik.

Ketersediaan tema kursus (course design) yang sesuai dengan pembelajar dalam program MOOC sangat menentukan keberhasilan peningkatan kualitas pembelajaran khususnya tentang pembelajaran keislaman. Course design terkait keislaman di dalam MOOC nasional maupun internasional masih sangat minim. Hanya beberapa saja yang membahasnya seperti MOOC edX membuka kelas tentang Religion, Conflict and Peace, Arab-Islamic History : From Tribes to Empires, The Legacy of Islamic Civilization, Islam Through Its Scriptures, Introduction to the Quran: The Scripture of Islam, MOOC FutureLearn membuka kelas tentang Muslims in Britain: Changes and Challenges, The Qur'an Between Judaism and Christianity, MOOC BCU membuka kelas tentang Meriam Ibrahim: The Case that Gripped the World, MOOC saylor.org membuka kelas tentang Islam, The Middle East, and The West, Ancient Civilizations of the World.

\section{Kesimpulan}

Kesimpulan dari penelitian ini adalah peluang meningkatkan kualitas proses dan hasil pembelajaran di Pendidikan Agama Islam masih sangat terbuka seiring dengan 
berkembangnya media pembelajaran di era digital yaitu Massive Open Online Course (MOOC) dengan berbagai variasinya yang adaptif. Apalagi saat ini diperkuat dengan program merdeka belajar yang memberikan peluang pembelajar dalam mengembangkan pengetahuan dan kemampuannya melalui pengalaman di luar kampus selama 2 semester dan di luar program studi selama 1 semester. Selama pelaksanaan pembelajaran di luar kampus membutuhkan suatu media penghubung antara mahasiswa dengan dosen sehingga dapat diketahui perkembangan pengalaman dan pengetahuannya selama beraktivitas di luar kampus. Melalui MOOC yang adaptif dapat dibangun pembelajaran kolaboratif antar Perguruan Tinggi Agama Islam dalam bentuk konsorsium bersama. Setiap perguruan tinggi menunjuk dosen yang memiliki kapabilitas penggunaan dan penyusunan media pembelajaran online, memiliki kemampuan komunikasi yang baik dan interaktif. Melalui wadah konsorsium bersama MOOC ini, mahasiswa dapat mengikuti program merdeka belajar secara online di bawah bimbingan dosen pendamping.

\section{Daftar Pustaka}

Abbakumov, D., Desmet, P., \& den Noortgate, W. Van. (2018). Measuring student's proficiency in MO0Cs: Multiple attempts extensions for the Rasch model. Heliyon, 4 (12), e01003. https://doi.org/10.1016/j.heliyon.2018.e01003

Abidin, J., \& Fahmi, I. (2019). MEDIA SOSIAL DALAM MEMPENGARUHI PERILAKU KEBERAGAMAAN SISWA DAN SOLUSINYA MELALUI PENDIDIKAN AGAMA ISLAM. Wahana Karya Ilmiah, 3 (01).

Aidemark, J., \& Askenäs, L. (2019). Fall Prevention as Personal Learning and Changing Behaviors: Systems and Technologies. Procedia Computer Science, 164, 498-507. https://doi.org/10.1016/j.procs.2019.12.212

Allison, C., Miller, A., Oliver, I., Michaelson, R., \& Tiropanis, T. (2012). The Web in education. Computer Networks, 56 (18), 3811-3824. https://doi.org/10.1016/j.comnet.2012.09.017

Amamou, S., \& Cheniti-Belcadhi, L. (2018). Tutoring In Project-Based Learning. Procedia Computer Science, 126, 176-185. https://doi.org/10.1016/j.procs.2018.07.221

Amirudin, N. (2019). Problematika Pembelajaran Pendidikan Agama Islam di Era Digital. Prosiding Seminar Nasional PAI dengan Pendekatan Multidisipliner, 181-192.

Baturay, M. H. (2015). An Overview of the World of MOOCs. Procedia - Social and Behavioral Sciences, 174, 427-433. https://doi.org/10.1016/j.sbspro.2015.01.685

Bertrand, S., Marzat, J., Besnerais, G. Le, Manzanera, A., Maniu, C. S., \& Makarov, M. (2019). Integrating Experimental Data Sets and Simulation Codes for Students into a MOOC on Aerial Robotics**The DroMOOC e-learning project has been funded by AAP IDEX 2017 Paris-Saclay, Numerique pour la formation a distance, in the context of Universite Paris-S. IFAC-PapersOnline, 52 (9), 50-55. https://doi.org/10.1016/j.ifacol.2019.08.123

Bilfaqih, Y., \& Qomarudin, M. N. (2015). Esensi Pengembangan Pembalajaran Daring. 131. Borrás-Gené, 0. (2019). Empowering MOOC participants: Dynamic content adaptation through external tools. Dalam Lecture Notes in Computer Science (including subseries 
Lecture Notes in Artificial Intelligence and Lecture Notes in Bioinformatics): Vol. 11475 LNCS. https://doi.org/10.1007/978-3-030-19875-6_14

Brahimi, T., \& Sarirete, A. (2015). Learning outside the classroom through MOOCs. Computers in Human Behavior, 51, 604-609. https://doi.org/10.1016/j.chb.2015.03.013

Cai, S., Luo, Q., Fu, X., \& Fang, B. (2020). What drives the sales of paid knowledge products? A two-phase approach. Information \& Management, 103264. https://doi.org/10.1016/j.im.2019.103264

Chrysantina, A., Sanjaya, G., Pinard, M., \& Hanifah, N. (2019). Improving Health Information Management Capacity with Digital Learning Platform: The Case of DHIS2 Online Academy. Procedia Computer Science, 161, 195-203. https://doi.org/10.1016/j.procs.2019.11.115

Cohen, A., \& Soffer, T. (2015). Academic Instruction in a Digital World: The Virtual TAU Case. Procedia - Social and Behavioral Sciences, 177, 9-16. https://doi.org/10.1016/j.sbspro.2015.02.322

Douglas, K. A., Merzdorf, H. E., Hicks, N. M., Sarfraz, M. I., \& Bermel, P. (2020). Challenges to assessing motivation in MOOC learners: An application of an argument-based $\begin{array}{llll}\text { approach. Computers \& } & 103829 .\end{array}$ https://doi.org/10.1016/j.compedu.2020.103829

Fikri, A. (2019). Pengaruh Globalisasi dan Era Disrupsi terhadap Pendidikan dan NilaiNilai Keislaman. Sukma: Jurnal Pendidikan, 3 (1), 117-136.

García-Peñalvo, F. J., Fidalgo-Blanco, Á., \& Sein-Echaluce, M. L. (2018). An adaptive hybrid MOOC model: Disrupting the MOOC concept in higher education. Telematics and Informatics, 35 (4), 1018-1030. https://doi.org/10.1016/j.tele.2017.09.012

Gardair, C., Bousquet, G., de Bazelaire, C., Lehmann-Che, J., de Cremoux, P., Nhieu, J. T. Van, Battistella, M., Sockeel, M., Calvani, J., Peuchmaur, M., Molina, T., Gervais, J., Moenaert, E., Pottier, Y., Prévaut, L., Sekri, K., \& Bertheau, P. (2017). Massive open online course (MOOC) sur le diagnostic des cancers: Bilan et évaluation de l'impact sur la perception de l'anatomie et cytologie pathologiques. Annales de Pathologie, 37 (2), 144-150. https://doi.org/10.1016/j.annpat.2017.02.001

Gregory, S., Bannister-Tyrrell, M., Charteris, J., \& Nye, A. (2018). Heutagogy in Postgraduate Education: Cognitive Advantages for Higher Degree Online Students. 189-209. https://doi.org/10.1007/978-981-10-5249-1_32

Hase, S. (2009). Heutagogy and e-learning in the workplace: Some challenges and opportunities. Impact: Journal of Applied Research in Workplace E-learning, 1 (1), 43-52. https://doi.org/10.5043/impact.13

Hew, K. F., \& Cheung, W. S. (2014). Students' and instructors' use of massive open online courses (MOOCs): Motivations and challenges. Educational Research Review, 12, 4558. https://doi.org/10.1016/j.edurev.2014.05.001

Irmayani, H., Wardiah, D., \& Kristiawan., M. (2018). The strategy of SD Pusri in improving educational quality. International Journal of Scientific and Technology Research, 7 (7), 113-121.

Islam, N., Beer, M., \& Slack, F. (2015). E-Learning Challenges Faced by Academics in Higher Education: A Literature Review. Journal of Education and Training Studies, 3 (5), 102-112. https://doi.org/10.11114/jets.v3i5.947 
Joksimović, S., Dowell, N., Poquet, O., Kovanović, V., Gašević, D., Dawson, S., \& Graesser, A. C. (2018). Exploring development of social capital in a CMOOC through language and discourse. The Internet and Higher Education, 36, 54-64. https://doi.org/10.1016/j.iheduc.2017.09.004

Kaplan, A. M., \& Haenlein, M. (2016). Higher education and the digital revolution: About MOOCs, SPOCs, social media, and the Cookie Monster. Business Horizons, 59 (4), 441-450. https://doi.org/10.1016/j.bushor.2016.03.008

Karnouskos, S. (2017). Massive open online courses (MOOCs) as an enabler for competent employees and innovation in industry. Computers in Industry, 91, 1-10. https://doi.org/10.1016/j.compind.2017.05.001

Kesim, M., \& Altınpulluk, H. (2015). A Theoretical Analysis of M00Cs Types from a Perspective of Learning Theories. Procedia - Social and Behavioral Sciences, 186, 1519. https://doi.org/10.1016/j.sbspro.2015.04.056

Lambert, S. R. (2020). Do MOOCs contribute to student equity and social inclusion? A systematic review 2014-18. Computers \& Education, 145, 103693. https://doi.org/10.1016/j.compedu.2019.103693

Lei, Z., Zhou, H., \& Hu, W. (2019). Combining MOOL with MOOC to Promote Control Engineering Education: Experience with NCSLab. IFAC-PapersOnline, 52 (9), 236241. https://doi.org/10.1016/j.ifacol.2019.08.207

Løkse, M., Låg, T., Solberg, M., Andreassen, H. N., \& Stenersen, M. (2017). Chapter SixTeaching It All. Dalam M. Løkse, T. Låg, M. Solberg, H. N. Andreassen, \& M. Stenersen (Ed.), Teaching Information Literacy in Higher Education (hlm. 81-145). Chandos Publishing. https://doi.org/10.1016/B978-0-08-100921-5.00006-0

Malek, J. A. (2017). The Impact of Heutagogy Education Through Telecentre in Smart Village (Sv). e-Bangi, 14 (2), 112-125.

Mawardi, I. (2013). Pendidikan Islam Transdisipliner Dan Sumber Daya. MPI Media Pendidikan Islam, XXVIII, No (Pendidikan Islam), 253-268.

Mukti, F. D. (2018). INTEGRASI LITERASI SAINS DAN NILAI-NILAI AKHLAK DI ERA GLOBALISASI. Abdau: Jurnal Pendidikan Madrasah Ibtidaiyah, 1 (2), 318-338.

Mustaghfiroh, S. (2020). Konsep "Merdeka Belajar" Perspektif Aliran Progresivisme John Dewey. Jurnal Studi Guru dan Pembelajaran, 3 (1 SE-Regular Articles). https://doi.org/10.30605/jsgp.3.1.2020.248

Nana, N., \& Surahman, E. (2019). Pengembangan Inovasi Pembelajaran Digital Menggunakan Model Blended POE2WE di Era Revolusi Industri 4.0. Prosiding SNFA (Seminar Nasional Fisika dan Aplikasinya), $4, \quad 82$. https://doi.org/10.20961/prosidingsnfa.v4i0.35915

Oey-Gardiner, M., Rahayu, S. I., Abdullah, M. A., Effendi, S., Darma, Y., Dartanto, T., \& Aruan, C. D. D. P. A.-1. pdfaniela D. (2007). Era Disrupsi: Peluang Dan Tantangan Pendidikan Tinggi Indonesia. https://doi.org/10.1016/S0925-2312 (96)00046-X

Otto, D., Caeiro, S., Nicolau, P., Disterheft, A., Teixeira, A., Becker, S., Bollmann, A., \& Sander, K. (2019). Can MOOCs empower people to critically think about climate change? A learning outcome based comparison of two MOOCs. Journal of Cleaner Production, 222, 12-21. https://doi.org/10.1016/j.jclepro.2019.02.190

Pangeni, S. K. (2017). Open and Distance Learning: Cultural Practices in Nepal. Dalam European Journal of Open, Distance and E-Learning (Vol. 19, Nomor 2, hlm. 32-45). 
https://doi.org/10.1515/eurodl-2016-0006

Praherdhiono, H., Setyosari, P., Degeng, I. N. S., Slamet, T. I., Surahman, E., Adi, E. P., Degeng, M. D. K., \& Abidin, Z. (2019). Teori dan Implementasi Teknologi Pendidikan: Era Belajar Abad 21 dan Revolusi Industri 4.0. Seribu Bintang.

Prasetyo, D., Marzuki, M., \& Riyanti, D. (2019). Pentingnya Pendidikan Karakter Melalui Keteladanan Guru. HARMONY, 4 (1), 19-32.

Prawitasari, B., \& Suharto, N. (2020). The Role of Guru Penggerak (Organizer Teacher) in Komunitas Guru Belajar (Teacher Learning Community) BT - 3rd International Conference on Research of Educational Administration and Management (ICREAM 2019). 86-89. https://doi.org/10.2991/assehr.k.200130.145

Rahmawati, F. (2018). Kecenderungan Pergeseran Pendidikan Agama Islam di Indonesia Pada Era Disrupsi. TADRIS: Jurnal Pendidikan Islam, 13. https://doi.org/10.19105/tjpi.v13i2.1752

Ramírez-Montoya, M.-S., Mena, J., \& Rodríguez-Arroyo, J. A. (2017). In-service teachers' self-perceptions of digital competence and OER use as determined by a xMOOC training course. Computers in Human Behavior, 77, 356-364. https://doi.org/10.1016/j.chb.2017.09.010

Reflianto, \& Syamsuar. (2019). Pendidikan dan tantangan pembelajaran berbasis teknologi informasi di era revolusi imdustri 4.0. Jurnal Ilmiah Teknologi Pendidikan, $6(2), 1-13$.

Rosidin. (2016). Problematika pendidikan islam perspektif Maqasid shari`ah. Jurnal Studi Keislaman, 3 (1).

Stokols, D. (2018). 4-Rise of the Internet-Navigating Our Online and Place-Based Ecologies. Dalam D. Stokols (Ed.), Social Ecology in the Digital Age (hlm. 89-136). Academic Press. https://doi.org/10.1016/B978-0-12-803113-1.00004-1

Sumarsono, S. (2020). The paradigms of heutagogy and cybergogy in the transdisciplinary perspective. Jurnal Pendidikan dan Pengajaran, 52 (3), 172-182.

Suwandaru, A., Hasan, M. S., \& Wijono, H. A. (2018). Model Pendidikan Kemandirian Pribadi Santri Melalui Konsep Amal Shaleh. PROCEEDING: The Annual International Conference on Islamic Education, 3 (1), 377-391.

Topîrceanu, A. (2017). Gamified learning: A role-playing approach to increase student inclass motivation. Procedia Computer Science, 112, 41-50. https://doi.org/10.1016/j.procs.2017.08.017

Torres-Coronas, T., \& Vidal-Blasco, M.-A. (t.t.). MOOC and Blended Learning Models: Analysis from a Stakeholders' Perspective. Dalam International Journal of Information and Communication Technology Education (Vol. 13, Nomor 3, hlm. 8899).

Watted, A., \& Barak, M. (2018). Motivating factors of MOOC completers: Comparing between university-affiliated students and general participants. The Internet and Higher Education, 37, 11-20. https://doi.org/10.1016/j.iheduc.2017.12.001

Weinhardt, J. M., \& Sitzmann, T. (2019). Revolutionizing training and education? Three questions regarding massive open online courses (MOOCs). Human Resource Management Review, 29 (2), 218-225. https://doi.org/10.1016/j.hrmr.2018.06.004

Wrigley, C., Mosely, G., \& Tomitsch, M. (2018). Design Thinking Education: A Comparison of Massive Open Online Courses. She Ji: The Journal of Design, Economics, and 
Innovation, 4 (3), 275-292. https://doi.org/10.1016/j.sheji.2018.06.002

Zhang, A. (2019). The Application and Research of MOOC Teaching in Accounting Profession Under the Background of "Internet +." 2019 International Conference on Virtual Reality and Intelligent Systems (ICVRIS), 255-258. https://doi.org/10.1109/ICVRIS.2019.00070

Zhu, M., \& Bonk, C. J. (t.t.). Designing M00Cs to Facilitate Participant Self-Monitoring for Self-Directed Learning. Dalam Online Learning (Vol. 23, Nomor 4, hlm. 106-134). 